\title{
Role of MerC, MerE, MerF, MerT, and/or MerP in Resistance to Mercurials and the Transport of Mercurials in Escherichia coli
}

\author{
Yuka Sone, ${ }^{a}$ Ryosuke Nakamura, ${ }^{a}$ Hidemitsu Pan-Hou, ${ }^{b}$ Tomoo Itoh,${ }^{a}$ and Masako Kiyono*, \\ ${ }^{a}$ Department of Public Health and Molecular Toxicology, School of Pharmacy, Kitasato University; 5-9-1 Shirokane, \\ Minato-ku, Tokyo 108-8641, Japan: and ${ }^{b}$ Faculty of Pharmaceutical Sciences, Setsunan University; 45-1 Nagaotoge- \\ cho, Hirakata, Osaka 573-0101, Japan. \\ Received July 14, 2013; accepted August 22, 2013; advance publication released online August 28, 2013
}

\begin{abstract}
The characteristics of bacteria take up mercury into cells via membrane potential-dependent sequencedivergent members of the mercuric ion (Mer) superfamily, i.e., a periplasmic mercuric ion scavenging protein (MerP) and one or more inner membrane-spanning proteins (MerC, MerE, MerF, and MerT), which transport mercuric ions into the cytoplasm, have been applied in engineering of bioreactor used for mercurial bioremediation. We engineered bacteria to express MerC, MerE, MerF, or MerT with or without MerP to clarify their individual role and potential in transport of mercurial. By immunoblot analysis using specific polyclonal antibody, the proteins encoded by merC, merE, merF, merT or merP, were certainly expressed and identified in the membrane fraction. Bacteria expressing MerC, MerE, MerF or MerT in the absence of MerP transported significantly more $\mathrm{C}_{6} \mathrm{H}_{5} \mathrm{Hg}(\mathrm{I})$ and $\mathrm{Hg}(\mathrm{II})$ across bacterial membrane than their isogenic strain. In vivo expression of MerP in the presence of all the transporters did not cause apparent difference to the $\mathrm{C}_{6} \mathrm{H}_{5} \mathrm{Hg}(\mathrm{I})$ transport, but gives an apparently higher $\mathrm{Hg}(\mathrm{II})$ transport than that did by MerE, MerF or MerT but not by MerC. Among the four transporters studied, MerC showed more potential to transport $\mathrm{Hg}$ (II) across bacterial membrane than MerE, MerF and MerT. Together these findings, we demonstrated for the first time that in addition to MerE and MerT, MerF and MerC are broad-spectrum mercury transporters that mediate both $\mathrm{Hg}(\mathrm{II})$ and phenylmercury transport into cells. Our results suggested that MerC is the most efficient tool for designing mercurial bioremediation systems, because MerC is sufficient for mercurial transport into cells.
\end{abstract}

Key words $\operatorname{mer} C$; $\operatorname{merE}$; $\operatorname{merF}$; merP; merT; mercurial transporter

Mercury is the most toxic heavy metal because of its high affinity for the sulfhydryl ligands in amino acids, which alters the structure of proteins after binding, often leading to a loss of function. ${ }^{1)}$ Mercury affects ecosystems and human health, and the increasing prevalence of this metal in the environment is a growing problem. Thus, there is an urgent need to develop cost-effective, sustainable, and environmentally friendly methods that facilitate the removal of mercury from contaminated sites.

Bioremediation using bacteria or plants is often regarded as a relatively inexpensive and efficient method for cleaning up waste, sediments, and soils contaminated with toxic mercury. ${ }^{2)}$ In general, the rehabilitation of metal-contaminated soils by plants requires a long time. McGrath and Zhao reported that several months were required to reduce the mercury content of contaminated soils by half. ${ }^{3)}$ The expression of bacterial mercury transporters in plants may improve mercury uptake, thereby shortening the time required to complete the purification process.

Bacteria can be used for bioremediation because they take up mercury via membrane potential-dependent sequence-diverged members of the mercuric ion (Mer) superfamily, i.e., a periplasmic $\mathrm{Hg}(\mathrm{II})$-scavenging protein (MerP) and one or more inner membrane-spanning proteins (MerC, MerE, MerF, and MerT), which transport $\mathrm{Hg}(\mathrm{II})$ into the cytoplasm. ${ }^{4-11)}$ These proteins have two, three, or four transmembrane domains (TMD), but TMD I and II are found in all members of the superfamily. ${ }^{12)}$ In all these proteins, one pair of cysteine residues is predicted to reside within the inner membrane, with or

The authors declare no conflict of interest. without a second pair of cysteine residues on the cytoplasmic face. $\mathrm{Hg}(\mathrm{II})$ is thought to pass into the cytoplasm by a series of exchange reactions between paired cysteine thiols in MerP and MerT led to the so-called "baseball glove" model. The baseball glove model consists of binding of $\mathrm{Hg}$ (II) initially by pair of vicinal cysteins in MerP, followed by sequential passing of $\mathrm{Hg}(\mathrm{II})$ from glove to glove in MerT. ${ }^{5)}$ The mechanism of transport of $\mathrm{Hg}(\mathrm{II})$ across the bacterial membrane mediated by $\operatorname{mer} C, \operatorname{mer} E, \operatorname{mer} F$ or $\operatorname{mer} T$ has been well studied. ${ }^{6,11,13-16)}$ However there is no direct experimental evidence concerning bacterial transport of organomercury until recently.

In the present study, to clarify the individual role and potential of MerC, MerE, MerF, or MerT in transport of mercurial, the merC or merE gene from Tn21 in the Shigella flexneri plasmid NR1 (R100), merF gene from the Pseudomonas fluorescens plasmid pMER327/419 or merT gene from Pseudomonas K-62 plasmid pMR26 with or without a periplasmic $\mathrm{Hg}(\mathrm{II})$-binding protein gene, merP from pMR26 were cloned into $E$. coli under control of mercury inducible regulatory part, merR-operator/promoter $(\mathrm{o} / \mathrm{p})$ genes from the mer-operon of pMR26 (Table 1).

Here we showed for the first time that in addition to MerE and MerT, MerC and MerF are broad-spectrum mercury transporters that mediate both $\mathrm{C}_{6} \mathrm{H}_{5} \mathrm{Hg}$ (I) and $\mathrm{Hg}$ (II) transport into cells. In addition, our results showed that coexpression of MerP with the four mercury transporters did not cause apparent difference to the $\mathrm{C}_{6} \mathrm{H}_{5} \mathrm{Hg}(\mathrm{I})$ transport, but gave higher $\mathrm{Hg}$ (II) transport than the expression of MerE, MerF or MerT alone. Among the four transporters, MerC showed highest potential for $\mathrm{Hg}(\mathrm{II})$ transport across the bacterial membrane. 
Table 1. Strains and Plasmids Used in This Study

\begin{tabular}{|c|c|c|}
\hline Strains and plasmids & Description of relevant feature(s) & Reference or source \\
\hline \multicolumn{3}{|l|}{ Strains } \\
\hline E. coli XL1-Blue & $\begin{array}{l}\text { recAl endA1 gyrA96 thi hsdR17 supE44 relA1 lac } /\left[\mathrm{F}^{\prime}:: \mathrm{Tn} 10 \mathrm{proAB}^{+} \text {lacl }^{\mathrm{q}}\right. \\
\quad \text { lacZM15 traD36] }\end{array}$ & Bullock et al. (1987) \\
\hline \multicolumn{3}{|l|}{ Plasmids } \\
\hline $\mathrm{pE} 4$ & $m e r R-\mathrm{o} / \mathrm{p}-m e r E$ in $\mathrm{pKF} 19 \mathrm{k}$ & Kiyono et al. (2009) \\
\hline $\mathrm{pF} 17$ & $m e r R-\mathrm{o} / \mathrm{p}-m e r F$ in $\mathrm{pKF} 19 \mathrm{k}$ & This study \\
\hline pT5 & $m e r R-\mathrm{o} / \mathrm{p}-m e r T$ in $\mathrm{pKF} 19 \mathrm{k}$ & This study \\
\hline $\mathrm{pC} 7$ & $m e r R-\mathrm{o} / \mathrm{p}-m e r C$ in $\mathrm{pKF} 19 \mathrm{k}$ & This study \\
\hline pPE62 & $m e r R$-o/p-merP-merE in pKF $19 \mathrm{k}$ & This study \\
\hline pPF8 & $m e r R-\mathrm{o} / \mathrm{p}-m e r P-m e r F$ in $\mathrm{pKF} 19 \mathrm{k}$ & This study \\
\hline pTP4 & $m e r R$-o/p-merT-merP in pKF19k & Sone et al. (2010) \\
\hline pPC20 & $m e r R-\mathrm{o} / \mathrm{p}-m e r P-m e r C$ in $\mathrm{pKF} 19 \mathrm{k}$ & This study \\
\hline
\end{tabular}

\section{MATERIALS AND METHODS}

Computer Analyses of Protein Sequences The transmembrane helices of individual proteins were predicted using FASTA-formatted sequences, which were analyzed with the TMHMM program. ${ }^{17)}$ The topologies of MerE, MerF, MerT, and MerC were analyzed using the SOSUI program, which predicts the $\mathrm{N}$-terminal and $\mathrm{C}$-terminal regions located in the cytoplasm.

Bacterial Strain, Plasmids, and Growth Conditions Escherichia coli (E. coli) XL1-Blue harboring pKF19K, ${ }^{18)}$ a cloning vector, was grown at $37^{\circ} \mathrm{C}$ in Luria-Bertani (LB) medium and used for routine plasmid propagation. The medium was supplemented with $25 \mu \mathrm{g} / \mathrm{mL}$ kanamycin as necessary.

Enzymes and Reagents The restriction enzymes, DNA ligation kits, and Taq polymerase were obtained from Takara Shuzo Corp. (Kyoto, Japan). The mercury was analytical reagent grade and was purchased from Wako Pure Chemical Industries, Ltd. (Tokyo, Japan).

Plasmid Construction The plasmids pF17, pT5, and $\mathrm{pC}$, which carried the $m e r R-\mathrm{o} / \mathrm{p}-m e r F$, merR-o/p-merT, and merR$\mathrm{o} / \mathrm{p}-$ merC genes, respectively, were constructed in $\mathrm{pKF} 19 \mathrm{k}$, as follows, whereas the construction of $\mathrm{pE} 4$ has been described previously. ${ }^{19)}$ The primers UKpnmerF (5'-GGGGTACCA TGA AAG ACC CGA AGA CAC T- $3^{\prime}$ ) and LEcomerF (5'-CGG AAT TCTCAT TTT TTT ACTCCATTGA-3') were used to amplify the merF region $(0.25 \mathrm{~kb})$ of $\mathrm{Tn} 5053$ (accession no. L40585) in the plasmid pUC18F. ${ }^{11)}$ After digesting the polymerase chain reaction (PCR) product with KpnI and EcoRI, the fragment was cloned into the KpnI-EcoRI site of pR2, ${ }^{19}$ ) which contained the merR-o/p gene of plasmid pMR26 (accession no. D83080) from pKF19k. The cloned fragment was sequenced and the resulting plasmid was designated as pF17. The primers UKpnmerT (5'-GGGGTACCA TGTCTGAAC CACAAA ACG G-3') and LEcomerT (5'-CGGAAT TCT TAA TAGAAAAATGGA ACGA-3') were used to obtain the merT region $(0.35 \mathrm{~kb})$ of pMR26. After digesting the PCR product with $K p n \mathrm{I}$ and EcoRI, the fragment was cloned into the KpnIEcoRI site of plasmid pR2 and the cloned fragment was sequenced, where the resulting plasmid was designated pT5. The primers UKpnmerC (5'-GGGGTACCA TGGGACTGA TGA CAC GCA T-3') and LEcomerC (5'-CGGAAT TCTCACAAG CGCTTGGCGGGGA-3') were used to amplify the merC region $(0.46 \mathrm{~kb})$ of $\operatorname{Tn} 21$ (accession no. AF071413). After digesting the PCR product with $K p n I$ and EcoRI, the fragment was cloned into the KpnI-EcoRI site of plasmid pR2 and the cloned fragment was sequenced, where the resulting plasmid was designated as $\mathrm{pC} 7$.

The plasmids pPE62, pPF8, and pPC20, which carried the merR-o/p-merP-merE, merR-o/p-merP-merF, and merR-o/pmerP-mer $C$ genes, respectively, were constructed in $\mathrm{pKF} 19 \mathrm{k}$ as follows, whereas pTP4 was constructed as described previously. ${ }^{20)}$ A $0.5 \mathrm{~kb}$ fragment containing the merP-merE genes from plasmid pTPE2 $1^{20)}$ was PCR-amplified using the primers UKpnmerP (5'-GGGGTA CCA TGA AGA AAC TGT TTGCCT C-3') and LEcomerE (5'-CGGAAT TCTCAT GATCCGCCC CGGAAGGC-3'), which contained KpnI and EcoRI sites. After digesting the PCR product with KpnI and EcoRI, the fragment was cloned into the KpnI-EcoRI site of vector pR2 and sequenced, where the resulting plasmid was designated as pPE62. The primers UXbaSDmerF (5'-GCTCTAGAT TCG AAA GGA CAA GCG CAT GAA AGA CCC GAA GAC ACT-3') and LEcomerF were employed to amplify the merF region $(0.25 \mathrm{~kb})$ using $\mathrm{Tn} 5053$ as a template, and the primers UXbaSDmerC (5'-GCTCTA GAT TCGAAA GGA CAA GCG CATGGGACTGATGACACGCAT-3') and LEcomerC were employed to amplify the merC region $(0.46 \mathrm{~kb})$ using $\mathrm{Tn} 21$ as a template. After digesting the PCR products with $X b a \mathrm{I}-$ $E c o$ RI, the fragments were cloned into the $X b a \mathrm{I}-E c o$ RI sites of pPE62, including one $X b a$ I site between the merP and merE genes. The cloned fragments were sequenced and the resulting plasmids were designated pPF8 and pPC20. The structures of the relevant genes and the restriction sites in the plasmids constructed in this study are shown in Table 1.

Preparation of Specific Antibodies Plasmid pMRD141, which contained merR-o/p-merT-merP from pMR26, was used as the template for the PCR amplification of a $0.3 \mathrm{~kb}$ $X b a \mathrm{I}-B g l \mathrm{II}$ fragment containing merP. The primers used were UP1117Xba (5'-GCTCTA GAT TCC ATT TTTCTA TTA-3') and LP1412Bgl (5'-GAA GATCTC TTC TTC AGC TCAGAT-3'), which contained restriction sites for $X b a \mathrm{I}$ and $B g l \mathrm{II}$, respectively. After digestion with $X b a \mathrm{I}$ and $B g l \mathrm{II}$, the fragment was cloned into the corresponding sites in plasmid pTUE1122, ${ }^{21)}$ which had a $6 \times$ His tag-encoding sequence, and the recombinant plasmid pMUP1122 was transformed into $E$. coli cells. E. coli transformants that carried pMUP1122 were grown in $200 \mathrm{~mL}$ of LB broth supplemented with $50 \mu \mathrm{g}$ of ampicillin per $\mathrm{mL}$ at $37^{\circ} \mathrm{C}$ for $3 \mathrm{~h}$ in the exponential growth phase, before $1 \mathrm{~mm}$ isopropyl- $\beta$-D-thiogalactopyranoside was added to the culture and the cells were incubated for a further 
$3 \mathrm{~h}$ at $37^{\circ} \mathrm{C}$. The MerP-His-tagged recombinant protein was purified by affinity chromatography using Ni-nitrilotriacetic acid agarose beads (Qiagen, Chatsworth, CA, U.S.A.), according to the manufacturer's instructions. One milliliter of purified MerP-His-tagged protein $(0.2 \mathrm{mg} / \mathrm{mL})$ was mixed well with $2 \mathrm{~mL}$ of complete Freund's adjuvant (Difco) and $3 \mathrm{~mL}$ of the emulsion was injected into a healthy rabbit. After 2 weeks, a mixture of the same amount of protein and $2 \mathrm{~mL}$ of incomplete Freund's adjuvant (Difco) was injected. Two weeks after the second immunization, antisera against the relevant antigen MerP were obtained.

To obtain a large volume of MerF or MerT-His ${ }_{6}$-tagged protein for antibody production, the proteins were expressed using a baculovirus-silkworm expression system (Katakura Industries Co., Ltd., Saitama, Japan). The primers UXhomerF (5'-CCGCTC GAG ATG AAA GAC CCGAAG ACA C-3') and LXbamerFhistag (5'-GCT CTA GAT TAG TGA TGG TGA TGG TGA TGT TTT TTT ACTCCA TTGAAT-3'), or UXhomerT (5'-CCGCTC GAG ATG TCT GAA CCACAA AAC- $3^{\prime}$ ) and LXbamerThistag (5'-GCT CTA GAT TAG TGA TGG TGA TGG TGA TGA TAGAAAAATGGAACGAC-3'), were used to produce $\operatorname{mer} F(0.25 \mathrm{~kb})$ from $T n 5053$ or $\operatorname{mer} T(0.35 \mathrm{~kb})$ from pMR26, respectively. The PCR fragments of $\operatorname{mer} F$ or $m e r T$ his tag were inserted into the XhoI-XbaI site in the transfer vector pM01 (Katakura Industries Co., Ltd., Saitama, Japan) and sequenced. The transfer vector and linearized genomic DNA from the $\mathrm{ABv}$ baculovirus (Bombyx mori nucleopolyhedrovirus; CPd strain; Katakura Industries Co., Ltd., Saitama, Japan) ${ }^{22)}$ were co-transfected into $B$. mori-cultured cells $(\mathrm{BmN}){ }^{23)}$ After propagating the recombinant baculovirus con-

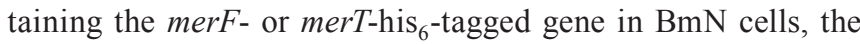
virus was used to infect silkworm pupae. Six days after inoculation, the infected pupae $(40 \mathrm{~g})$ were homogenized in $140 \mathrm{~mL}$ of homogenization buffer $(20 \mathrm{~mm}$ Tris- $\mathrm{HCl}, \mathrm{pH} 8.0,0.15 \mathrm{M}$ $\mathrm{NaCl}, 1 \mathrm{~mm}$ ethylenediamine tetraacetic acid (EDTA), $1 \mathrm{~mm}$ ethylene glycol bis(2-aminoethylether)- $N, N, N^{\prime}, N^{\prime}$-tetraacetic acid (EGTA), 10\% glycerol, $1 \mathrm{~mm}$ dithiothreitol (DTT), $1 \mathrm{~mm}$ phenylmethylsulfonyl fluoride, and $10 \mathrm{~mm}$ benzamidine) and centrifuged for $1 \mathrm{~h}$ at $100000 \times \boldsymbol{g}$ and $4^{\circ} \mathrm{C}$, and the supernatant was discarded. The pellet was resuspended in $140 \mathrm{~mL}$ of homogenization buffer with $1 \%$ Triton X-100. After incubation with stirring for $1 \mathrm{~h}$ at $4^{\circ} \mathrm{C}$, the suspension was centrifuged, as described above, and the pellet was discarded. The supernatant was applied to a Ni-agarose column and the column was washed with wash buffer $(25 \mathrm{~mm}$ Tris- $\mathrm{HCl}, \mathrm{pH} 8.0,0.25 \mathrm{~m}$ $\mathrm{NaCl}, 1 \mathrm{~mm}$ EDTA, 5\% glycerol, and $0.5 \%$ Triton X-100). The

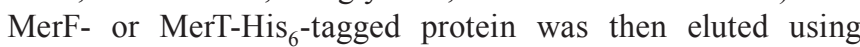
elution buffer (100mm Tris- $\mathrm{HCl}, \mathrm{pH} 8.0,0.3 \mathrm{~m} \mathrm{NaCl}, 1 \mathrm{~mm}$ EDTA, 5\% glycerol, $0.3 \%$ Triton X-100, and $0.4 \mathrm{M}$ imidazole). Fractions that contained the MerF- or MerT-His ${ }_{6}$-tagged protein were pooled and frozen at $-80^{\circ} \mathrm{C}$ until further use. The

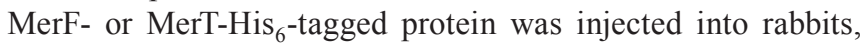
and the anti-MerF and anti-MerT antibodies were prepared by Operon Biotechnology (Tokyo, Japan).

The anti-MerC or anti-MerE antibodies were prepared as described previously. ${ }^{19)}$

Subcellular Fractionation, Sodium Dodecyl Sulfate-Polyacrylamide Gel Electrophoresis (SDS-PAGE), and Western Blot Analysis E. coli XL1-Blue cells that contained the plasmids pE4, pF17, pT5, pC7, pPE62, pPF8, pTP4, or pPC20 were grown to an optical density of 0.80 at $600 \mathrm{~nm}$ with
$0.5 \mu \mathrm{M} \mathrm{HgCl}_{2}$. The cells were centrifuged, washed with buffer (50 mm Tris-HCL, pH 8.0, 0.15 M NaCl, $1 \mathrm{~mm}$ EDTA, and $10 \%$ glycerol), and suspended in $1.2 \mathrm{~mL}$ of the same buffer. The harvested cells were disrupted by sonication in the presence of $80 \mu \mathrm{m}$ phenylmethylsulfonyl fluoride, $2 \mathrm{~mm}$ benzamidine, and $0.25 \mu \mathrm{g} / \mathrm{mL}$ leupeptin. Undisrupted cells were removed by low-speed centrifugation. The cell homogenate was centrifuged at $104000 \times \boldsymbol{g}$ for $30 \mathrm{~min}$. After centrifugation, the pellet containing the membrane fraction was suspended in $1.2 \mathrm{~mL}$ of wash buffer supplemented with $1 \%$ Triton X-100.

The soluble (supernatant) and particulate fractions were boiled with an equal volume of $2 \times$ Laemmli's sample buffer for $5 \mathrm{~min}$. SDS-PAGE was performed using $12.5 \%$ minigels. The proteins were separated by SDS-PAGE and transferred to an Immobilon-P membrane (Millipore, Billerica, U.S.A.). After blocking with de-fatted milk, the membrane filter was incubated with anti-MerE, ${ }^{19)}$ anti-MerF, anti-MerT, anti-MerC, ${ }^{19)}$ or anti-MerP antibodies to detect the proteins of interest. The membranes were washed and reacted with peroxidase-conjugated anti-rabbit immunoglobulin G (IgG) (Sigma-Aldrich, MO, U.S.A.). Chemiluminescent ECL reagents (GE Healthcare, Giles, U.K.) were used to detect the antigens. The membranes were washed with PBS plus $0.1 \%$ Tween 20 and reacted with peroxidase-conjugated anti-rabbit IgG (Sigma-Aldrich, MO, U.S.A.) for $1 \mathrm{~h}$. After washing, the immunoreactive bands were visualized using an ECL detection kit (GE Healthcare, Chalfont, St. Giles, U.K.).

Mercurial Resistance Assay The mercurial $\left(\mathrm{C}_{6} \mathrm{H}_{5} \mathrm{HgOCOCH} \mathrm{HgCl}_{3}\right.$ or $\left.\mathrm{HgCl}_{2}\right)$ resistance capacities of $E$. coli strain XL1-Blue cells that carried pKF19k (control vector) or recombinants were determined in liquid medium. Cells that carried the control or constructs were grown overnight at $37^{\circ} \mathrm{C}$ in $\mathrm{LB}$ broth containing $25 \mu \mathrm{g} / \mathrm{mL}$ kanamycin. The cells were harvested and suspended in LB broth $\left(8 \times 10^{7}\right.$ cells $/ 200 \mu \mathrm{L} /$ well) containing various concentrations of $\mathrm{C}_{6} \mathrm{H}_{5} \mathrm{HgOCOCH}_{3}$ or $\mathrm{HgCl}_{2}$. After incubation at $37^{\circ} \mathrm{C}$ for $16 \mathrm{~h}$, the absorbance of each culture was measured at $A_{600}$ to quantify the cell growth.

Mercurial Uptake Assay E. coli XL1-Blue cells carrying the control or recombinants (as described above) were grown overnight at $37^{\circ} \mathrm{C}$ in LB broth containing $25 \mu \mathrm{g} / \mathrm{mL}$ kanamycin. The cells were harvested and suspended in the original volume of $\mathrm{LB}$ broth and grown at $37^{\circ} \mathrm{C}$ until $\mathrm{OD}_{600}=1.00$. The cells were harvested and resuspended in LB broth containing $100 \mu \mathrm{g} / \mathrm{mL}$ chloramphenicol and $100 \mu \mathrm{M}$ EDTA. The cell suspensions were incubated for $30 \mathrm{~min}$ at $37^{\circ} \mathrm{C}$ with $5 \mu \mathrm{M}$ $\mathrm{C}_{6} \mathrm{H}_{5} \mathrm{HgOCOCH}_{3}$ or $10 \mu \mathrm{M} \mathrm{HgCl}_{2}$. Aliquots $(0.5 \mathrm{~mL})$ were harvested and washed three times with $\mathrm{LB}$ broth containing $100 \mu \mathrm{g} / \mathrm{mL}$ chloramphenicol and $100 \mu \mathrm{m}$ EDTA. After digestion with concentrated nitric acid for $1 \mathrm{~h}$ at $90^{\circ} \mathrm{C}$, the total mercury was measured using an atomic absorption spectrometry analyzer HG-310 (Hiranuma, Mito, Japan).

\section{RESULTS}

Analysis of the Protein Sequences and Localization of MerE, MerF, MerT, MerC, and MerP The mature MerP is a periplasmic $\mathrm{Hg}(\mathrm{II})$-binding protein of about 80 amino acids, which is synthesized with a cleavable N-terminal leader, and $\mathrm{Hg}(\mathrm{II})$ is bound to the sequence GMTCXXC. Hydropathy prediction programs indicated that MerE from Shigella flexneri and MerF from Pseudomonas fluorescens contained 
A.

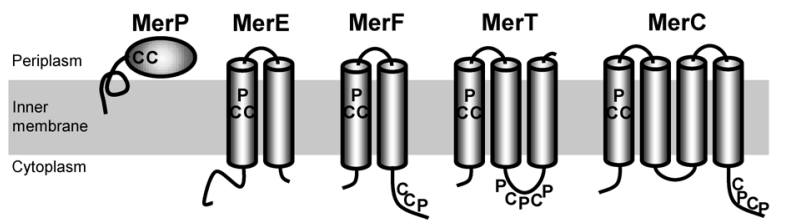

B.

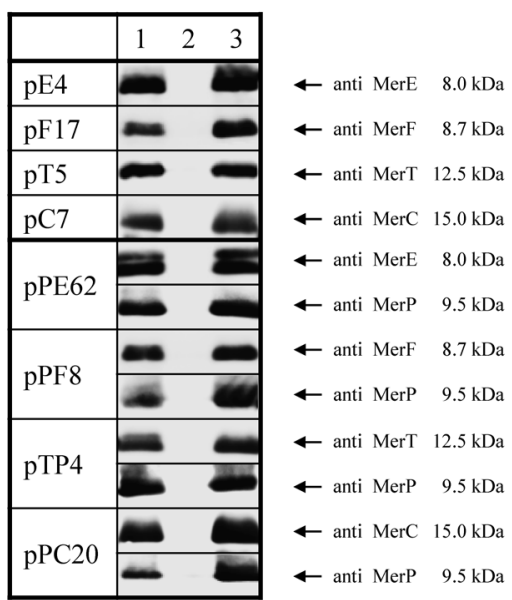

Fig. 1. Topological Alignment of pMR26 MerP, R100 MerE, pMER327/419 MerF, pMR26 MerT, and R100 MerC Amino Acids According to Their Predicted Hydrophobic Elements (A), and Western Blot Analyses of the Five Proteins (B)

The crude cell extracts (lane 1), soluble fractions (lane 2), and membrane fractions (lane 3) of the transformant strains containing plasmids pE4, pF17, pT5, pC7, pPE62, pPF8, pTP4, and pPC20 were analyzed using anti-MerE, anti-MerF anti-MerT, anti-MerC, and anti-MerP polyclonal antibodies. E. coli XL1-Blue cells containing the plasmids pE4, pF17, pT5, pC7, pPE62, pPF8, pTP4, or pPC20 were generated and grown with $\mathrm{Hg}(\mathrm{II})$, as described in Materials and Methods. The arrows indicate MerE (8.0 kDa), MerF (8.7 kDa), MerT (12.5 kDa), MerC (15.0kDa), and MerP $(9.5 \mathrm{kDa})$.

two membrane-spanning regions, whereas MerT from Pseudomonas strain K-62 had three and MerC from Shigella flexneri had four (Fig. 1A). In each case, the first region contained two closely positioned cysteine residues and a nearby distal proline residue (Fig. 1A). With the exception of MerE, each protein also contained an additional pair of cysteine residues, which were predicted to be located in the cytoplasm, with an adjacent proline (Fig. 1A). In MerF and MerC, this region was close to the carboxyl terminal, whereas it was located between TMDs II and III in MerT (Fig. 1A).

To determine how MerE, MerF, MerT, MerC, and MerP cooperate during mercurial uptake, recombinant plasmids were constructed that contained the merR-o/p and merE, $\operatorname{merF}$, merT, or $\operatorname{mer} C$ genes, with or without $\operatorname{mer} P$ (Table 1). Mer protein expression in the transformants was measured by immunoblot analysis using polyclonal anti-MerE, ${ }^{19)}$ antiMerF, anti-MerT, anti-MerC, ${ }^{19)}$ and anti-MerP antibodies with SDS-PAGE. The following novel protein bands were identified in the crude cell extracts and membrane fractions from cells that contained pE4, pF17, pT5, pC7, pPE62, pPF8, pTP4, and pPC20 (Fig. 1B, lanes 1 and 3): a band with a molecular mass of $8.0 \mathrm{kDa}$ that reacted specifically with the anti-MerE antibody, a band with a molecular mass of $8.7 \mathrm{kDa}$ that reacted specifically with the anti-MerF antibody, a band with a molecular mass of $12.5 \mathrm{kDa}$ that reacted specifically with the anti-MerT antibody, a band with a molecular mass of $15 \mathrm{kDa}$ that reacted specifically with the anti-MerC antibody, and/ or a band with a molecular mass of $9.5 \mathrm{kDa}$ that reacted spe-

\section{A. Without MerP}

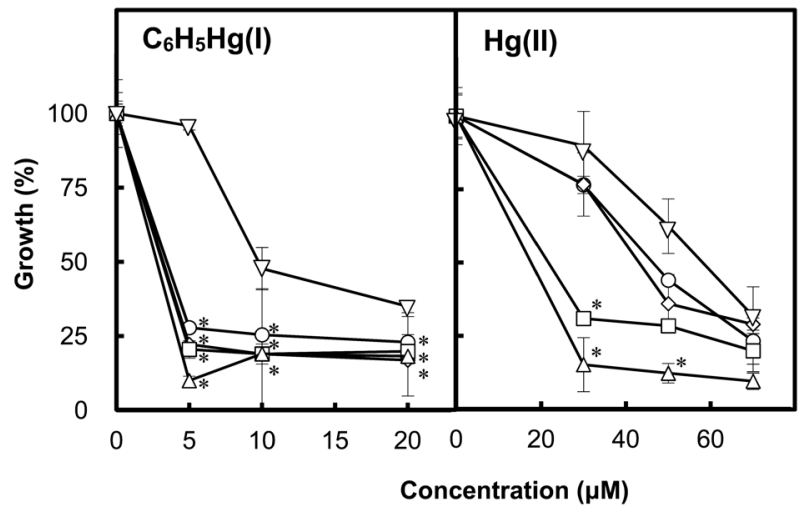

B. With MerP

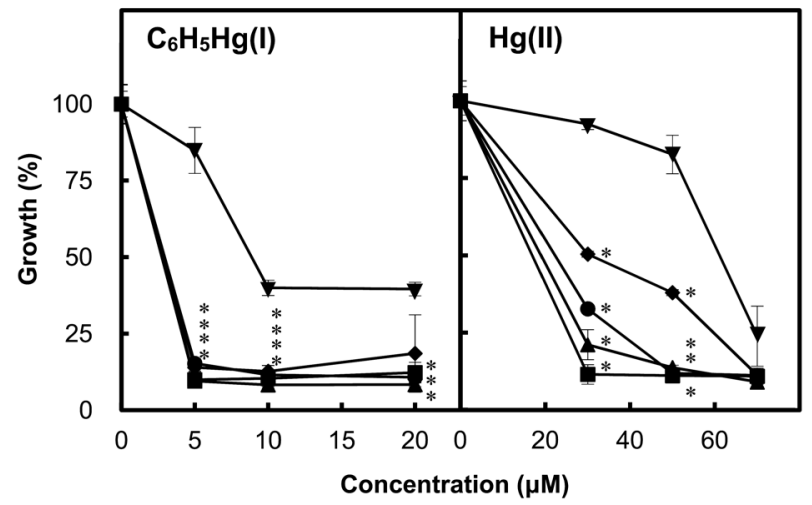

Fig. 2. Mercury Susceptibility of Recombinant E. Coli Cells That Expressed MerE, MerF, MerT, or MerC without MerP (A) and with MerP (B)

E. coli XL1-Blue cells that contained the vectors pKF19k (open or closed inverted triangles), pE4 (open circles), pF17 (open diamonds), pT5 (open squares), pC7 (open triangles), pPE62 (closed circles), pPF8 (closed diamonds), pTP4 (closed squares), or pPC20 (closed triangles) were grown, prepared, and assayed as described in Materials and Methods. All of the values represent the means of triplicate determinations from three independent experiments. The values are expressed as the mean \pm standard deviation. The asterisk indicates significant differences from the control value at the same time point $\left({ }^{*} p<0.01, t\right.$-test $)$

cifically with the anti-MerP antibody. The protein sizes were consistent with those predicted based on the translations of the DNA sequences of the $\operatorname{merE}, \operatorname{merF}, \operatorname{mer} T, \operatorname{mer} C$, and $\operatorname{mer} P$ genes, respectively.

Mercury Resistance and Mercury Uptake The resistance to and accumulation of $\mathrm{Hg}(\mathrm{II})$ or $\mathrm{C}_{6} \mathrm{H}_{5} \mathrm{Hg}(\mathrm{I})$ by cells containing the vectors pKF19k, pE4 (MerE), pF17 (MerF), pT5 (MerT), pC7 (MerC), pPE62 (MerP-MerE), pPF8 (MerPMerF), pTP4 (MerT-MerP), pPC20 (MerP-MerC), or pPE62 (MerP-MerE) were examined. Figure 2 shows the mercury susceptibility of recombinant $E$. coli cells that expressed MerE, MerF, MerT, or MerC without MerP (A) and with MerP (B). The cells with MerE or MerF were more sensitive to $\mathrm{Hg}(\mathrm{II})$ and $\mathrm{C}_{6} \mathrm{H}_{5} \mathrm{Hg}(\mathrm{I})$ than their isogenic cells with the cloning vector (Fig. $2 \mathrm{~A}$ ). The cells with MerT or MerC were more sensitive to $\mathrm{Hg}(\mathrm{II})$ and $\mathrm{C}_{6} \mathrm{H}_{5} \mathrm{Hg}(\mathrm{I})$ than MerE and MerF (Fig. 2A). The $\mathrm{Hg}(\mathrm{II})$ resistance levels of the cells that co-expressed MerP and MerE/MerF were lower than that of the control (Fig. 2B). Cells with MerT-MerP or MerP-MerC were also more sensitive to $\mathrm{Hg}(\mathrm{II})$ compared with MerP-MerE and MerP-MerF (Fig. 2B). By contrast, the $\mathrm{C}_{6} \mathrm{H}_{5} \mathrm{Hg}(\mathrm{I})$ resistance levels of cells 

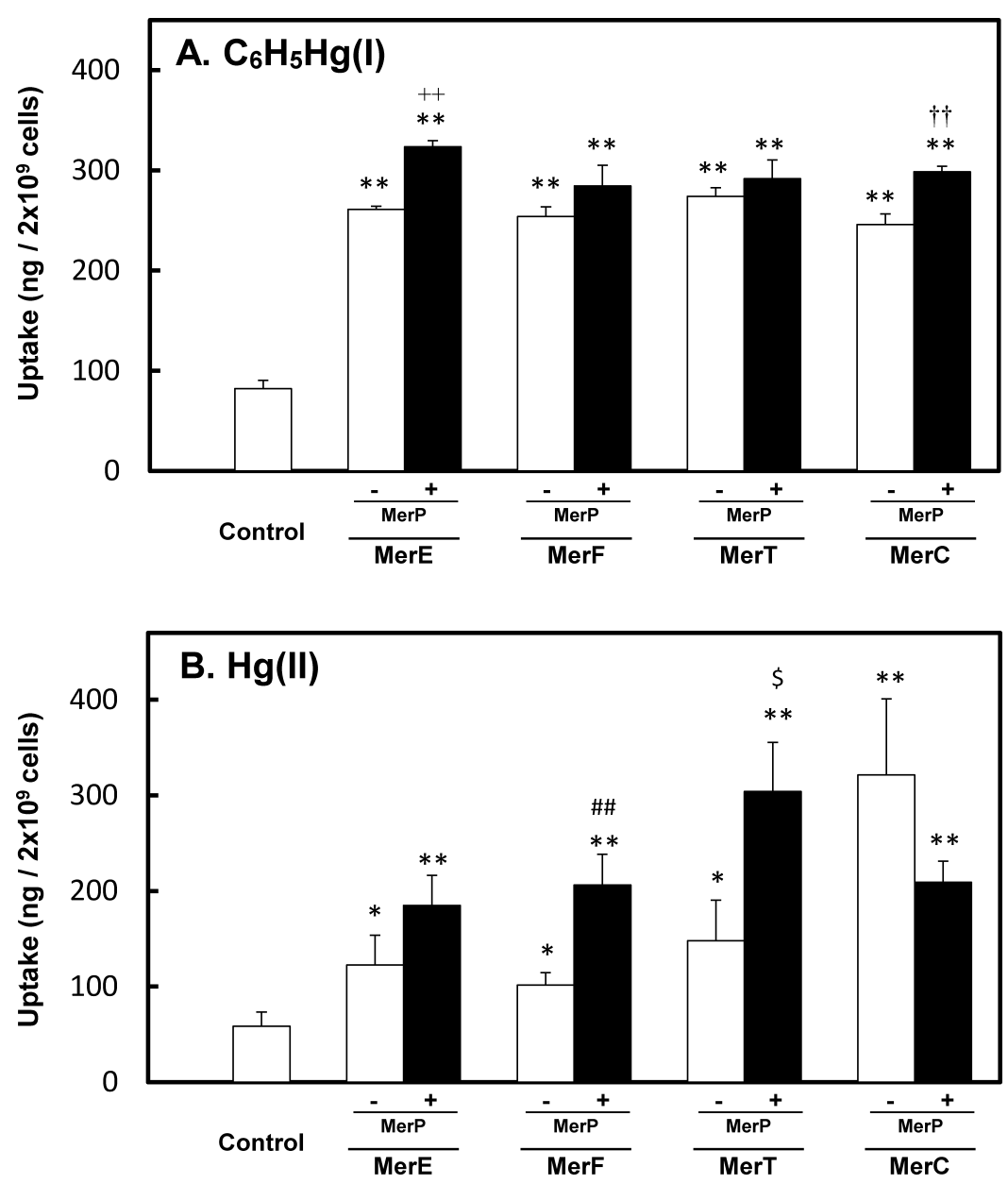

Fig. 3. Bacterial Uptake of $\mathrm{C}_{6} \mathrm{H}_{5} \mathrm{Hg}(\mathrm{I})$ or $\mathrm{Hg}(\mathrm{II})$

E. coli XL1-Blue cells containing the vectors pKF19k (control), pE4 (open bar), pPE62 (closed bar), pF17 (open bar), pPF8 (closed bar), pT5 (open bar), pTP4 (closed bar), pC7 (open bar), or pPC20 (closed bar) were grown, prepared, and assayed as described in Materials and Methods. All of the values represent the means of triplicate determinations from three experiments. The values are expressed as the mean \pm standard deviation. ${ }^{*} p<0.05$ and $* * p<0.01 v s$. control; ${ }^{++} p<0.01 v s$. pE4; ${ }^{\# \#} p<0.01 v s$. $\mathrm{pF} 17 ;{ }^{\$} p<0.05$ vs. pT5; ${ }^{\dagger \dagger} p<0.01$ vs. pC7.

that expressed MerE, MerF, MerT, or MerC, with or without MerP, were lower that of the control (Fig. 2B).

As shown in Fig. 3A, the cells that expressed MerE, MerF, MerT, or MerC accumulated significantly more $\mathrm{C}_{6} \mathrm{H}_{5} \mathrm{Hg}(\mathrm{I})$ than their isogenic cells with the cloning vector, pKF19k. Coexpression of MerP with MerE, MerF, MerT, or MerC did not cause increased $\mathrm{C}_{6} \mathrm{H}_{5} \mathrm{Hg}(\mathrm{I})$ accumulation than the cell expressed transporter alone (Fig. 3A). In contrast, cells that expressed MerE, MerF, MerT, or MerC accumulated significantly more $\mathrm{Hg}(\mathrm{II})$ than their isogenic cells with the cloning vector, pKF19k. Among the four transporters, MerC showed more potential to accumulate $\mathrm{Hg}$ (II) than MerE, MerF, or MerT. Cells co-expressing MerP with MerE, MerF, or MerT accumulated significantly more $\mathrm{Hg}(\mathrm{II})$ than the cells that lacking MerP, however MerP did not cause increased the MerC-specified $\mathrm{Hg}$ (II) accumulation (Fig. 3B).

\section{DISCUSSION}

Bioremediation is an economical and effective technology for dealing with a wide variety of contaminants. However this technology is a slow process that requires a long time to complete the purification. This potential fault may predominantly result from low mercury-uptake activity and thereby limit its usefulness for practical application. Among the strategies being used to overcome this disadvantage is use of mercury transporter to boost the uptake and transport of mercurial into bacteria or plant cells. Several lines of evidence suggest that accelerated mercury uptake and enhanced mercury accumulation is a particularly promising strategy for improving the bioreactor to be more suitable for use in remediation of mercurials. ${ }^{24,25)}$

In the present study, the efficiency and potential of the known mercury transporters, MerC, MerE, MerF or MerT, and whether these proteins are also involved in the transport of organomercurial was investigated. The mer $C$, merE, merF or merT, genes cloned in $E$. coli were certainly translated into proteins with molecular masses of $15 \mathrm{kDa}, 8 \mathrm{kDa}, 8.7 \mathrm{kDa}$ or $12.5 \mathrm{kDa}$, respectively, which were located in the membrane fraction, in cells (Fig. 1B). By hydropathy analysis we predicted that MerC, MerE, MerF and MerT had, respectively, four, two, two and three transmembrane regions. Each protein has a cysteine pair located in the first transmembrane regions: Cys-Cys in MerT and MerF, Cys-Pro-Cys in MerE, and CysAla-Ala-Cys in MerC which have been shown to be essential for $\mathrm{Hg}(\mathrm{II})$ transport into the cell. In addition, in all four proteins, proline residue is conserved on the $\mathrm{C}$-terminal site of this cysteine motif. These observations are consistent with the 
results previously obtained..$^{6,11,13-16)}$

Bacteria expressing MerC, MerE, MerF or MerT showed more sensitivity not only to $\mathrm{Hg}(\mathrm{II})$ but also to $\mathrm{C}_{6} \mathrm{H}_{5} \mathrm{Hg}(\mathrm{I})$ than their isogenic control strain independently of MerP (Fig. 2). This hypersensitivity phenotype is thought to result from hyperaccumulation of toxic mercurials in the absence of mercury-detoxifying enzyme. The hypersensitivity phenotype to $\mathrm{C}_{6} \mathrm{H}_{5} \mathrm{Hg}(\mathrm{I})$ noted by the recombinants suggest for the first time that the four mercury transporters are involved in the $\mathrm{C}_{6} \mathrm{H}_{5} \mathrm{Hg}(\mathrm{I})$ transport across bacterial membrane. Indeed, bacteria expressing MerC, MerE, MerF or MerT in the absence of MerP took up appreciably more $\mathrm{C}_{6} \mathrm{H}_{5} \mathrm{Hg}(\mathrm{I})$ and $\mathrm{Hg}(\mathrm{II})$ than their isogenic cells without these transporters (Fig. 3). In vivo expression of MerP in the presence of MerC, MerE, MerF or MerT did not cause increased $\mathrm{C}_{6} \mathrm{H}_{5} \mathrm{Hg}(\mathrm{I})$ uptake than those in the absence of MerP (Fig. 3A). However, cells co-expressing MerP with MerE, MerF, or MerT, but not MerC, took up significantly more $\mathrm{Hg}(\mathrm{II})$ than the cells lacking MerP (Fig. 3B). Among the four transporters tested, MerC showed a relatively higher $\mathrm{Hg}$ (II) uptake in the absence of MerP (Fig. 3B). In the current model of mercury transport system, MerP has been shown to act primarily as a $\mathrm{Hg}$ (II) scavenger, binding $\mathrm{Hg}$ (II) and keeping it from other periplasmic proteins which require thiol groups for activity. ${ }^{5,26)}$ In addition MerP may increase the local concentration of $\mathrm{Hg}$ (II) in the periplasmic compartment and pass the $\mathrm{Hg}$ (II) to inner membrane transporter. Enhancement of $\mathrm{Hg}$ (II) uptake mediated by MerE, MerF or MerT in the presence of MerP (Fig. 3B) seems to be primarily resulted via the high local concentration of $\mathrm{Hg}$ (II) in the periplasmic compartment. However it would be curious why the $\mathrm{Hg}$ (II) uptake mediated by MerC did not activate by MerP. Further studies are required to achieve a more complete understanding of this discrepancy.

Bioremediation is highly attractive technology for mercury remediation from the contaminated sites but it is still in its infancy stage. Further study, for example, seeking a molecule that can sequester and retain the transported mercury into living cells but without taxing the cells is required for using mercury transporter in mercury remediation. We have previously shown that polyphosphate, a biomolecule is capable of reducing the cytotoxicity of the transported $\mathrm{Hg}(\mathrm{II})$ and retaining more mercury in the living cells but without the cells via chelation formation with polyphosphate. ${ }^{27-29)}$

In conclusion, this study showed for the first time that in addition to MerE and MerT, MerF and MerC are broadspectrum mercury transporters that mediate the transport of mercuric ions and phenylmercury. Thus, in addition, MerC is the most efficient tool for designing a potential bioreactor used in environmental bioaccumulation of mercurial pollution.

Acknowledgments We are grateful to Dr. K. Watabe and Dr. H. Takamatsu for their valuable advice and for the gift of the plasmid pTUE1122. We are also grateful to Dr. J. L. Hobman for his valuable advice and for the gift of the plasmid pUC18F. We thank Miss A. Ikawa, Miss N. Kaneko, Miss A. Takahashi, and Miss S. Sugita for their technical assistance. This work was supported in part by a Grant-in-Aid for Young Scientists (B) (No. 24790128) to Y.S. and a Grant-in-Aid for Scientific Research (C) (No. 24510104) to M.K. from the Ministry of Education, Culture, Sports, Science and Technology of Japan.

\section{REFERENCES}

1) Nies DH. Efflux-mediated heavy metal resistance in prokaryotes. FEMS Microbiol. Rev., 27, 313-339 (2003).

2) Malik A. Metal bioremediation through growing cells. Environ. Int., 30, 261-278 (2004)

3) McGrath SP, Zhao FJ. Phytoextraction of metals and metalloids from contaminated soils. Curr. Opin. Biotechnol., 14, 277-282 (2003).

4) Barkay T, Miller SM, Summers AO. Bacterial mercury resistance from atoms to ecosystems. FEMS Microbiol. Rev., 27, 355-384 (2003).

5) Silver S, Phung LT. Bacterial heavy metal resistance: new surprises. Annu. Rev. Microbiol., 50, 753-789 (1996).

6) Brown NL, Shih YC, Leang C, Glendinning KJ, Hobman JL, Wilson JR. Mercury transport and resistance. Biochem. Soc. Trans., 30, 715-718 (2002).

7) Liebert CA, Hall RM, Summers AO. Transposon Tn21, flagship of the floating genome. Microbiol. Mol. Biol. Rev., 63, 507-522 (1999).

8) Kiyono M, Omura T, Inuzuka M, Fujimori H, Pan-Hou H. Nucleotide sequence and expression of the organomercurial-resistance determinants from a Pseudomonas K-62 plasmid pMR26. Gene, 189, 151-157 (1997).

9) Kiyono M, Pan-Hou H. DNA sequence and expression of a defective mer operon from Pseudomonas K-62 plasmid pMR26. Biol. Pharm. Bull., 22, 910-914 (1999).

10) Kiyono M, Pan-Hou H. The $\operatorname{mer} G$ gene product is involved in phenylmercury resistance in Pseudomonas strain K-62. J. Bacteriol., 181, 726-730 (1999).

11) Wilson JR, Leang C, Morby AP, Hobman JL, Brown NL. MerF is a mercury transport protein: different structures but a common mechanism for mercuric ion transporters? FEBS Lett., 472, 78-82 (2000).

12) Mok T, Chen JS, Shlykov MA, Saier MH. Bioinformatic analyses of bacterial mercury ion $\left(\mathrm{Hg}^{2+}\right)$ transporters. Water Air Soil Pollut., 223, 4443-4457 (2012).

13) Sahlman L, Hagglof EM, Powlowski J. Roles of the four cysteine residues in the function of the integral inner membrane $\mathrm{Hg}^{2+}$-binding protein, MerC. Biochem. Biophys. Res. Commun., 255, 307-311 (1999).

14) Sahlman L, Wong W, Powlowski J. A mercuric ion uptake role for the integral inner membrane protein, MerC, involved in bacterial mercuric ion resistance. J. Biol. Chem., 272, 29518-29526 (1997).

15) Rossy E, Seneque O, Lascoux D, Lemaire D, Crouzy S, Delangle P, Coves J. Is the cytoplasmic loop of MerT, the mercuric ion transport protein, involved in mercury transfer to the mercuric reductase? FEBS Lett., 575, 86-90 (2004).

16) Schué M, Dover LG, Besra GS, Parkhill J, Brown NL. Sequence and analysis of a plasmid-encoded mercury resistance operon from Mycobacterium marinum identifies MerH, a new mercuric ion transporter. J. Bacteriol., 191, 439-444 (2009).

17) Krogh A, Larsson B, von Heijne G, Sonnhammer EL. Predicting transmembrane protein topology with a hidden Markov model. application to complete genomes. J. Mol. Biol., 305, 567-580 (2001).

18) Hashimoto-Gotoh T, Mizuno T, Ogasahara Y, Nakagawa M. An oligodeoxyribonucleotide-directed dual amber method for site-directed mutagenesis. Gene, 152, 271-275 (1995).

19) Kiyono M, Sone Y, Nakamura R, Pan-Hou H, Sakabe K. The MerE protein encoded by transposon $\mathrm{Tn} 21$ is a broad mercury transporter in Escherichia coli. FEBS Lett., 583, 1127-1131 (2009).

20) Sone Y, Pan-Hou H, Nakamura R, Sakabe K, Kiyono M. Roles played by MerE and MerT in the transport of inorganic and organic mercury compounds in Gram-negative bacteria. J. Health Sci., 56, 123-127 (2010).

21) Takamatsu H, Hiraoka T, Kodama T, Koide H, Kozuka S, Tochikubo $\mathrm{K}$, Watabe $\mathrm{K}$. Cloning of a novel gene $y \mathrm{rbB}$, encoding a 
protein located in the spore integument of Bacillus subtilis. FEMS Microbiol. Lett., 166, 361-367 (1998).

22) Suzuki T, Kanaya T, Okazaki H, Ogawa K, Usami A, Watanabe H, Kadono-Okuda K, Yamakawa M, Sato H, Mori H, Takahashi S, Oda K. Efficient protein production using a Bombyx mori nuclear polyhedrosis virus lacking the cysteine proteinase gene. J. Gen. Virol., 78, 3073-3080 (1997).

23) Maeda S. Expression of foreign genes in insects using Baculovirus vectors. Annu. Rev. Entomol., 34, 351-372 (1989).

24) Kiyono M, Sone Y, Miyahara K, Oka Y, Nakamura M, Nakamura R, Sato MH, Pan-Hou H, Sakabe K, Inoue K-i. Genetic expression of bacterial merC fused with plant SNARE in Saccharomyces cerevisiae increased mercury accumulation. Biochem. Eng. J., 56, 137-141 (2011).

25) Nagata T, Nakamura A, Akizawa T, Pan-Hou H. Genetic engineer- ing of transgenic tobacco for enhanced uptake and bioaccumulation of mercury. Biol. Pharm. Bull., 32, 1491-1495 (2009).

26) Morby AP, Hobman JL, Brown NL. The role of cysteine residues in the transport of mercuric ions by the Tn501 MerT and MerP mercury-resistance proteins. Mol. Microbiol., 17, 25-35 (1995).

27) Kiyono M, Omura H, Omura T, Murata S, Pan-Hou H. Removal of inorganic and organic mercurials by immobilized bacteria having mer-ppk fusion plasmids. Appl. Microbiol. Biotechnol., 62, 274-278 (2003).

28) Pan-Hou H, Kiyono M, Omura H, Omura T, Endo G. Polyphosphate produced in recombinant Escherichia coli confers mercury resistance. FEMS Microbiol. Lett., 207, 159-164 (2002).

29) Nagata T, Kiyono M, Pan-Hou H. Engineering expression of bacterial polyphosphate kinase in tobacco for mercury remediation. Appl. Microbiol. Biotechnol., 72, 777-782 (2006). 